\title{
Return on Investment for Scented Rice in One of the Green Revolution Province of India
}

\author{
Sudhanand Prasad Lal ${ }^{1 *}$, Sujeet Kumar Jha ${ }^{2}$ and Shrija Sinha ${ }^{2}$ \\ ${ }^{1}$ PG Department of Extension Education, Dr. Rajendra Prasad Central Agricultural \\ University, Pusa, Samastipur, Bihar-848125, India \\ ${ }^{2}$ Division of Dairy Extension, Indian Council of Agricultural Research-National Dairy \\ Research Institute, 132001, Haryana, India \\ *Corresponding author
}

\begin{tabular}{|c|c|}
\hline & $\mathbf{R} A \mathbf{C} \mathbf{T}$ \\
\hline Keywords & \multirow{4}{*}{$\begin{array}{l}\text { India is an agrarian economy where around } 50 \text { percent of their population is employed } \\
\text { through this sector and to the contrary agriculture and allied sectors contributes only } 16.4 \\
\text { per cent in } 2017-18 \text { to the Indian GDP. Rice is one of the three most imperative food crops } \\
\text { in the India. The study was done during the agricultural year of } 2016-2017 \text { to analyze the } \\
\text { differences in Return on Investment (ROI); when farmers own the land and when it is } \\
\text { rented. Haryana is divided into } 3 \text { zones and from each zones one district was randomly } \\
\text { selected. } 60 \text { paddy growers from each of the } 3 \text { districts of Haryana were selected randomly } \\
\text { pooling which made an initial sample size of } 180 \text {. But not all paddy cultivators were } \\
\text { basmati grower and so } 37 \text { from Karnal, } 22 \text { from Rohtak and } 9 \text { from Rewari were the } \\
\text { scented paddy grower and thus making the actual respondents size of } 68 \text {. The study } \\
\text { concludes that cultivation of scented rice is only plausibly profitable when the farmer own } \\
\text { the land. It was also visible that as high as } 35.80 \text { percent of the total cost is spent by the } \\
\text { farmer in renting the land. The ROI when land is rented is } 7.89 \text { percent; while when it is }\end{array}$} \\
\hline & \\
\hline Ar & \\
\hline & \\
\hline
\end{tabular}

\section{Introduction}

An endeavor initiated jointly by ford foundation and government of India, leveraged Indian agricultural scenario into a much revolutionized one. By the experimentation and espousal of different yield enhancing technologies and logistics; India's most potential food producing areas i.e. Haryana, Punjab and Uttar Pradesh became the centre for the cultivation and production of different paddy and wheat varieties. Through which these states earned a proud appellation of 'India's Bread Basket'. There are a lot of factors causative of the selfsustaining status of India, talking particularly about Haryana its dynamic political leadership, efficient infrastructure, upgraded and versatile agricultural technologies, land reforms and copious assistance has widely contributed to its current magnificent status. Currently, the average productivity of rice in 
the state is $3,256 \mathrm{Kg} / \mathrm{ha}$ which is comparatively higher than country's average of $2,416 \mathrm{~kg} / \mathrm{ha}$, alike situation prevails in case of state's wheat productivity which is recorded to be $1,577 \mathrm{~kg} /$ ha higher than nation's average productivity (Mustaquim, 2016).

It is quite clear from above description Haryana happens to be a leading contributor to the country's food grain pool. About $65 \%$ of the state's population lives in villages. The State Domestic Product (SDP) (both Gross and Net) increases approximately at the rate of $0.19 \%$ annually whereas in terms of per capita, SDP increased at a lower rates of $0.17 \%$ (Bhupal, 2012). Staple crop 'Rice' is grown in every districts of Haryana (RKMP, 2011). Total acreage of rice based on field survey has been estimated to be 1328948 ha in 20 districts of Haryana in which Karnal district has the highest transplanted area under rice of 166619 ha (APEDA, 2018). Main varieties adopted in the state are Pusa 1121, Pusa 1509, PB-1 and Sharbati. 4,28,000 ha of land in Haryana is used for the cultivation of 'Pusa 1121' which begets 1455000 tons of produce; while 'PB-1' is cultivated in 41200 ha and the production is 216900 tons; whereas 'Pusa 1509' is cultivated in 33600 ha and the production accounts for 134700 tons and 'Sharbati' is grown on 5800 ha and has a total production of 20100 tons (APEDA, 2018). Recently, with the change in the political leadership of the country the voice as well as actions to stand with the country's farmers has become clearer and louder. In 2016, our honourable Prime Minister based on the thoughtful recommendations of National Commission on Farmers called for doubling farm income by 2022 (Indian Council of Food and Agriculture, 2016). Reiterating the government's commitment to the goal of doubling farmers' income by 2022, in the Union Budget 2018, the government publicized its decision to offer a Minimum Support Price (MSP) of at least 1.5 times the expenses borne by farmers for all crops (Pravallika et al., 2017).

\section{Materials and Methods}

\section{Locale of Study and Sampling Plan}

For the study, Haryana was purposively selected and within that 3 districts were selected, one from each zone i.e. Karnal, Rohtak and Rewari. A report was issued by Agricultural and Processed Food Products Export Development Authority (APEDA), New Delhi entitled "Basmati Survey -2018 (APEDA, 2018)" talked about the basmati acerage and yield estimation in the seven leading basmati producing states of the country viz., Punjab, Haryana, Uttarakhand, Himachal Pradesh, western Uttar Pradesh and parts of Jammu \& Kashmir; out of total 508000 ha land which is under basmati cultivation in Haryana, Karnal has 47700 ha of it under the basmati cultivation which emanates it under high cultivation zone; while 30400 ha land is under basmati cultivation in Rohtak putting it under medium zone; 1300 ha land of Rewari is being used for the same, making the district fall under the low cultivation category. 60 paddy growers from each of the 3 districts were selected randomly pooling which made a total of 180 initial respondents for the study locale. It is noteworthy to mention here that not all paddy cultivators were basmati grower and so 37 from Karnal, 22 from Rohtak and 9 from Rewari were the scented paddy grower and thus making the actual respondent size of 68 .

In the present study ROI is calculated for two cases; case 1 deals with the situation in which the cultivated land is owned by the farmers and the case 2 deals with the situation where respondents may have to pay the rent of the land for cultivation. ROI as earlier mentioned is a performance measure used to estimate the efficiency of the investment done at the farm 
level. ROI is the current value of investment which is calculated by dividing benefit from the investment by the cost of the investment expressed in percentage or ratio (Chen, 2019). ROI evaluation is a three-phase model of assessment planning, data collection, and data analysis (Lynch et al., 2006).

ROI=

Current Value of Investment-Cost of Investment Cost of Investment $\mathrm{X} 100$

ROI is considered as the straightforward tool to analyse the investment, as discussed earlier ROI can be both expressed in percentage and in ratio. The results from the calculation can be either be negative or positive, a positive ROI shows that net return exceeds the cost of investment which is a good sign for the farm where as negative sign denotes a vice-versa situation clearly showing a undesirable picture of the farm. It is interesting to note here that if in case ROI of the farm happens to be positive, the magnitude of the value is of utmost importance greater the magnitude of the value greater is its profitability of the farm under study. When the farm has a positive ROI value, it is denoted in black; while when the value is negative it is denoted in red (Beattie, 2018).

\section{Results and Discussion}

As discussed earlier the contemplation of the results in this paper was done using two different cases which generally occurs at the farm level: farmers could either own the land on which they cultivate or can rent the same. There are almost ten prominent steps in which different cost incurred in the cultivation of scented rice is dispersed. The very first segment out of the ten is 'Nursery preparation and seedling's growth'. In this segment the cost spent on the seed is highest i.e. 400 units (Rs.) followed by money incurred in sowing (254.77 units), while money spent on Layout of 160 sq.m. land is 127.38 units; cost incurred in fertilizers applications of the nursery is 142.60 units. Similarly 50 units is spent both on seed treatment and weedicide application. Only 16 units are spent on discing of the nursery while for puddling and planking of nursery cost incurred by the farmers is thrice as of discing i.e. 48 units. This is because of the difference in the usage of tractor (35 HP) in case of discing it is used for only 0.04 hours while for other the tractor is used for 0.12 hours. Dealing with the second segment i.e. field preparation, out of the three sub-component farmers incurs highest on Puddling of the field ( 2766.67 units) following this is the cost incurred in discing of the field i.e. 640 units. Outlay spent on Laser land leveller is lowest in the segment i.e. only 216.67 units; as it is done once in a three year. The third segment in the row is transplanting, for this farmers spent a total of 2466.67 units of the total cost incurred.

Fourth major component amongst the segment is fertilization of the crop, the total cost incurred by the paddy farmer in this segment is 3528 units. The result found is in consistence with the findings from the study conducted by Basavarajappa and Chinnappa (2013) that the expenditure on FYM, fertilizers and pesticides cost was very high as the manures and fertilizers cost accounted for more than 50 percent of the cultivation cost in their study. Further expenditure on looping of the canopy was 318.46 units. Looping of canopy is important for the scented paddy because of its height, which make it prone to lodging. To prevent this, 10-12 inches leaves are cut from the top; if delayed it is cut up to $13 \mathrm{~cm}$, in vernacular the whole procedure is called 'patta katai (Leaf cutting)'. Except Pusa 1509 looping of canopy is done in Taraori Basmati 1, Pusa 1121 and CSR-30. The main reason for non- looping of canopy in Pusa 1509 is the lower plant height of $80 \mathrm{~cm}$ as against $120 \mathrm{~cm}$ for Pusa 1121 (RKMP, 2014). 
Now, another very important segment is 'irrigation'. In the present context this segment includes expenditure incurred on the labour used for irrigating the field, cost of canal irrigation, electric tube wells maintenance, electricity or pumping set as well as diesel cost.

Generally in a season 10-12 irrigation is required for the optimum growth of the paddy, here an average of ten irrigation is taken into consideration. One irrigation cost 200 units thus, total 2000 units are spent for irrigation of the field by the farmers.

Seventh segment is 'Plant Protection', in the scented rice cultivation three main chemical protection was used first is defense against white \& brown plant hopper which cost the farmers approximately 500 units, second is the protection against stem borers for which farms expends 400 units and third is the generalized sub-segment including money spent on weedicide, insecticides, fungicides etc and the labour charges; the total cost incurred in this sub-segment is almost 4000 units.

Thus, here it can be concluded that this segment involves second highest borne expenditure by the farmer which is 4900 units. Eighth segment is harvesting of the standing paddy crop, here it costs the highest i.e. 5000 units. The next segment is the cost of transportation and marketing which costs around 1200 units. Second last is the interest paid for six months charged at the rate of $12 \%$ per annum (excluding rental value of the land) making the expenditure made by the farmer in this segment to be 1455.16 units. The last segment in this series is the main theme giving uniqueness to this paper i.e. a comparison made between ROI when the land on which farmer cultivate the scented paddy is rented and the ROI when it is owned by the farmer. From the Table 1 it is clear that total cost of cultivation (with owned land) is $\quad 25,707.76$ units (Case 1); while with the rented land it is 40041.09 units (Case 2), which is more than 1.5 times as compared to the cost incurred in the Case 1. Gross benefit (in both the cases) is same i.e. 43200 units. With these data ROI was calculated. It was articulated that ROI (with rent of land) i.e. Case 2 was found to be $7.89 \%$; while ROI in Case 1 was found to be $68.04 \%$ (Table 1 ).

Since both the values are positive, magnitude of the value will further help in interpreting the results. It is clearly evident from the results that ROI in case 1 was multiple times higher than that of case second. Thus, one can very fervidly state that actual benefit to the farmers can only be achieved when they own the land.

From the Figure 1, it is visible that $35.80 \%$ of the total cost of cultivation is of rent of the land borne by the farmer, 12.49 percent of the cost is incurred in harvesting followed by plant protection i.e. $12.24 \%$ then field preparation accounts for $9.05 \%$ of the total cost. Fertilizer cost comes after that with $8.81 \%$ of the total cost.

Similarly Figure 2, describes the cost percentage when the land is not rented, in this case harvesting occupies $19.45 \%$ of the total cost almost similar percentage i.e. 19.06 per cent is devoted by farmer in plant protection measures. Following this, was the cost of field preparation and fertilizer application in the farm i.e. $14.09 \%$ and $13.72 \%$, respectively. It is very evident that apart from the cost incurred on the rent of the land, a quantum amount of money is spent on plant protection and fertilization this is in accordance of the study conducted by Marothia et al., (2007) where authors concluded that Integrated use of fertilizers and FYM shared the next highest expenditure, followed by seed and plant protection measures. 
Table.1 Cost of cultivation of scented paddy per acre in Haryana

\begin{tabular}{|c|c|c|c|c|}
\hline S.no. & Operation Material & Input & Rate & Cost (Rs) \\
\hline \multirow[t]{15}{*}{1.} & \multicolumn{4}{|l|}{ Nursery (160 Sq. m.) } \\
\hline & \multicolumn{4}{|l|}{ (a) Nursery preparation } \\
\hline & (i) One discing & $\begin{array}{l}\text { One tractor }(35 \\
\text { HP) for } 0.04 \text { hours }\end{array}$ & 400/hr. & 16.00 \\
\hline & (ii) Puddling and Planking & $\begin{array}{l}\text { One tractor ( } 35 \\
\text { HP) for } 0.12 \text { hours }\end{array}$ & 400/hr. & 48.00 \\
\hline & (b) Layout & 0.4 man day & $\begin{array}{l}\text { DC rate/man } \\
\text { day }\end{array}$ & 127.38 \\
\hline & (c) Sowing & 0.8 man days & $\begin{array}{c}\mathrm{DC} \text { rate } / \mathrm{man} \\
\text { day }\end{array}$ & 254.77 \\
\hline & (d) Seed & $8 \mathrm{~kg}$ & $50 / \mathrm{kg}$ & 400 \\
\hline & (e) Seed treatment & 1 times & & 50 \\
\hline & \multirow{5}{*}{$\begin{array}{l}\text { (f) Fertilizer and organic decomposed } \\
\text { manure }\end{array}$} & $2.8 \mathrm{~kg}$ Urea & $5.68 / \mathrm{kg}$ & 15.90 \\
\hline & & $2 \mathrm{~kg}$ DAP & $24 / \mathrm{kg}$ & 48.00 \\
\hline & & $1.2 \mathrm{~kg} \mathrm{MOP}$ & $15 / \mathrm{kg}$ & 18 \\
\hline & & $25 \mathrm{~kg}$ FYM & $1.5 / \mathrm{kg}$ & 37.50 \\
\hline & & $\begin{array}{l}0.4 \mathrm{~kg} \text { Zinc } \\
\text { sulphate } \\
\text { monohydrate }\end{array}$ & $58 / \mathrm{kg}$ & 23.20 \\
\hline & (g) Labour charge & 0.4 man day & DC rate/man day & 127.38 \\
\hline & (h) Weedicide & 1 times & & 50 \\
\hline \multirow[t]{4}{*}{2.} & \multicolumn{4}{|l|}{ Field preparation } \\
\hline & one discing & $\begin{array}{l}\text { One tractor }(35 \\
\text { HP) for } 1.6 \text { hours }\end{array}$ & $400 / \mathrm{hr}$. & 640.00 \\
\hline & Puddling & & & 2766.67 \\
\hline & $\begin{array}{l}\text { Laser land leveler (3hrs/acre @ } \\
\text { Rs.700/hour) }\end{array}$ & $\begin{array}{l}1 / 3(\text { per } 3 \\
\text { years)* } 1 / 2(6 \\
\text { mths) }\end{array}$ & & 216.67 \\
\hline 3. & Transplanting & In contract & & 2466.67 \\
\hline 4. & Fertilizer application & $\begin{array}{l}100 \mathrm{~kg} \text { Urea } \\
50 \mathrm{~kg} \text { DAP } \\
20 \mathrm{~kg} \text { Zinc } \\
\text { sulphate } \\
\text { monohydrate } \\
\text { Mycorrhizal } \\
\text { biofertilizer } \\
\text { Sesbania bispinosa }\end{array}$ & $\begin{array}{c}5.68 / \mathrm{kg} \\
24 / \mathrm{kg} \\
58 / \mathrm{kg} \\
\\
200 / \mathrm{kg} \\
400\end{array}$ & $\begin{array}{l}568 \\
1200 \\
1160 \\
200 \\
400\end{array}$ \\
\hline 5. & Looping of canopy & 1 man day & & 318.46 \\
\hline 6. & $\begin{array}{l}\text { Irrigation (comprises labour plus canal, } \\
\text { electric tubewells maintenance, } \\
\text { electricity or pumping set, diesel cost) }\end{array}$ & 10 times & 200/irrigation & 2000 \\
\hline \multirow[t]{2}{*}{7.} & Plant protection & & & \\
\hline & White \& Brown plant hopper & & & 500 \\
\hline
\end{tabular}




\begin{tabular}{|c|c|c|c|c|}
\hline & Stem borers & & & 400 \\
\hline & $\begin{array}{l}\text { Other spray for weeicide, insecticide, } \\
\text { fungicide etc. }\end{array}$ & & & 4000 \\
\hline 8. & Manual harvesting & & & 5000.00 \\
\hline 9. & Cost of transportation and marketing & & & 1200 \\
\hline \multirow[t]{2}{*}{10.} & $\begin{array}{l}\text { Interest for } 6 \text { months (excluding rental } \\
\text { value of land) }\end{array}$ & 6 months & $12 \%$ per annum & 1455.16 \\
\hline & $\begin{array}{l}\text { Total cost of cultivation } \\
\text { (with owned land) }\end{array}$ & & & $25,707.76$ \\
\hline \multirow[t]{2}{*}{11.} & $\begin{array}{l}\text { Rental value of land } \\
\text { (This is exclude in all those cases where } \\
\text { land is owned by the farmers) }\end{array}$ & 6 months & 28666.67/annum & 14333.33 \\
\hline & $\begin{array}{l}\text { Total cost of cultivation } \\
\text { (with rented land) }\end{array}$ & & & 40041.09 \\
\hline 12. & Production & 17q @ 2400/q & & 40800 \\
\hline 13 & Straw return & $12 q @ 200 / q$ & & 2400 \\
\hline 15. & Gross Benefit (in both the cases) & & & 43200 \\
\hline 16. & ROI ( with rent of land) & & & $7.89 \%$ \\
\hline 17. & ROI (with owned land) & & & $68.04 \%$ \\
\hline
\end{tabular}

Fig.1 Cost for various operations (With rented land)

\section{Cost for various Operations}

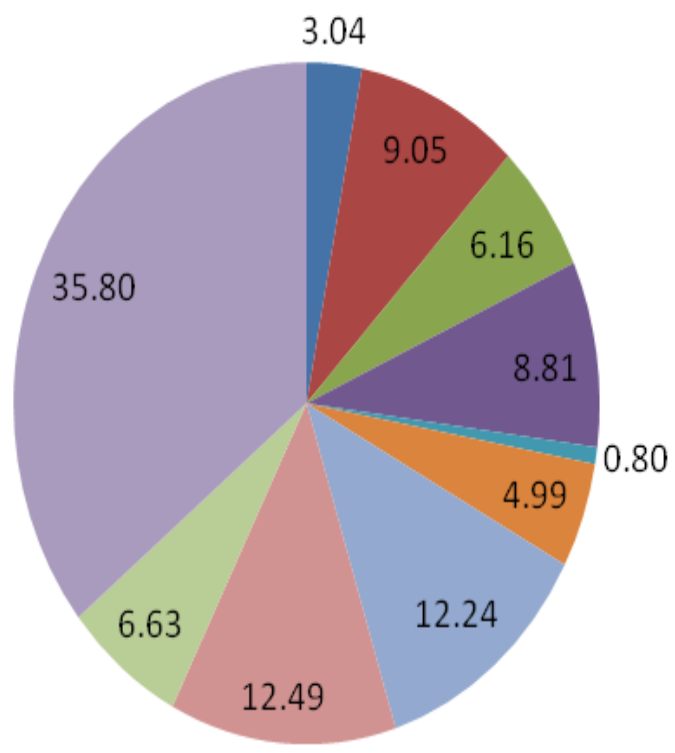

- Nursery preparation

Field Pre

Transplanting

- Fertilizer

- Looping

- Irrigation

PP

Harvesting

Transportation \& Intrest

Rent 
Fig.2 Cost for various operations (Without rented land)

\section{Cost of operations without rent}

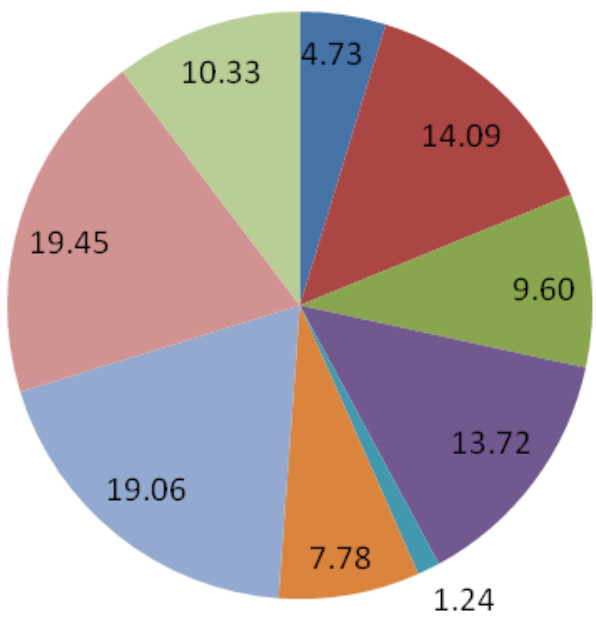

nursery preparation

Field Pre

- Transplanting

- Fertilizer

Looping

- Irrigation

aP

- Harvesting

- Transportation \& Intrest

It can be concluded that any business whether small or big, should surely have mechanism to judge the profitability of the investment done. There are many options available out of which Return on Investment is quite easy to understand and to calculate. They say 'the instinct of ownership is fundamental in man's nature', the quote is quite evident in the present research article, the ownership fetches the farmers more dividends while nonownership just helps them counter only the cost incurred in scented rice cultivation. It is suggestive from the paper that cultivation of scented rice is only profitable when the farmers cultivate it in his own land otherwise the cost of cultivation is increased by almost $36 \%$.

\section{References}

APEDA. (2018). Basmati Survey - Report-3., Basmati Acreage \& Yield Estimation in Punjab, Haryana, Delhi, Uttarakhand, Himachal Pradesh, Western Uttar Pradesh and Parts of Jammu \&
Kashmir. Geotrans Technologies Pvt. Ltd., Basmati Export Development Foundation, APEDA, New Delhi, pp. 52.

Basavarajappa, D.N. and Chinnappa, B. (2013). Economics of paddy in Bhadra command of Karnataka, Internat. Research Journal of Agricultural Economics \& Statistics. 4 (2): 139-142.

Beattie A. 2018. FYI on ROI: A Guide to Calculating Return on Investment. URL: https://www.investopedia.com/ articles/basics/10/guide-to-calculatingroi.asp

Bhupal, D.S. (2012). Agricultural Profile of Haryana. Agricultural Economics Research Centre, University of Delhi, pp.32.

Chen, J. 2019. What is Return on Investment (ROI). URL: https://www.investopedia. com/terms/r/returnoninvestment.asp

Indian Council of Food and Agriculture. 2016. Report on Doubling Farmer's Income by 2022 Farm Crisis and Farmers' Distress, India International 
Centre, New Delhi.

Lynch, K., Akridge, J.T., Schaffer, S.P., and

Gray, A. W. (2006). Framework for Evaluating Return on Investment in Management Development Programs. International Food and Agribusiness Management Review. 9 (2): 54-74.

Marothia, D.K., Singh, R.K., Chandrakar, M.R. and Jain, B.C. (2007). Economics and Marketing of Aromatic Rice - A Case Study of Chhattisgarh. Agricultural Economics Research Review., 20: 29-46.

Mustaquim, M. 2016. Green Revolution in Haryana: Facing Fallout. URL: https://www.ruralmarketing.in/industry/ agriculture/green-revolution-in-haryanafacing-fallout

Pravallika, K.V.S.D., Prasanna, P.A.L., and Choudhary, V.K. (2017).Economics of Paddy Cultivation in East Godavari district of Andhra Pradesh. Journal of Rice Research. 10 (2): 89-96.

RKMP. 2011. Rice Cultivation in Haryana. Rice Knowledge Management Portal. URL: http://www.rkmp.co.in/content/ricecultivation-in-haryana

RKMP. 2014. Pusa-1509, The next billiondollar basmati? URL: http://www.rkmp.co.in/category/newsevents-optional-tags/pusa-1509

\section{How to cite this article:}

Sudhanand Prasad Lal, Sujeet Kumar Jha and Shrija Sinha. 2019. Return on Investment for Scented Rice in One of the Green Revolution Province of India. Int.J.Curr.Microbiol.App.Sci. 8(03): 1305-1312. doi: https://doi.org/10.20546/ijcmas.2019.803.154 